\title{
Minority in English literary translation: the case of Slovak culture- bound items
}

\author{
Klaudia Bednarova-Gibova
}

\section{DOI: $10.18355 /$ XL.2017.10.03.16}

\begin{abstract}
The paper homes in on the analysis of culture-bound items in the English translation of the Slovak novel Rivers of Babylon (1991) which contains unique lexis symptomatic of the (post)-communist linguistic scene. By its focus on the transplantation of the Slovak culturally-marked lexis into English, the study is sensitively responsive to Cronin's appeal (2006) that in order to stand out in the globalized world it is necessary to start to pay heed to the local. The paper draws on the premise that when dealing with cultural asymmetries between languages cultural transplantation is inevitable, which supports the interpretation of translation as an essentially cultural practice (see Hermans, 2007). Ongoing research has shown that intercultural competence and awareness, arising from experience of cultures, are far more complex phenomena than they may seem to the translator. So far, less attention has been paid to the Central European context with focus on the Slovak culture transfer. The paper aims to investigate the character of the translation techniques used for the transfer of Slovak culture-bound items based on Pym's cutting-edge model of translation solutions (2016). The study also attempts to research the extent to which the local colour of the Slovak start text has been preserved in the English literary translation. Based on the corpus analysis, it may be argued that the translator tends to the reduction of the cultural expressiveness by domestication of culture-bound items in the target culture. The research findings are part of cultural translation and are instrumental in shedding fresh light on how Slovak culture may be reported to English culture.
\end{abstract}

Key words: culture, cultural translation, intercultural transfer, culture-bound items, translation solutions

\section{Introduction}

Culture has inextricably been linked to translation since its inception. In particular, since the so-called cultural turn which has swept translation studies with its focus on the interaction between translation and culture and on the way culture impacts translation, translating across cultures along with intercultural competence and awareness have become buzz words in the translation business. There is no maybe about it. In compliance with Cronin (2006), the conceptual focus of translation studies has of late shifted from interest in the global to the local, with cultural transfer being no exception. Thus, the present paper aims to examine how the local colour of the Slovak start text ${ }^{1}$, which represents a minor language, has been preserved in the English translation of Pištanek's novel Rivers of Babylon using Pym's most recent model of translation solutions (2016). More than a decade ago, research into minority languages and translation was "largely invisible" in translation studies (see Cronin, 2003: 153). Of the studies which have been written ever since, emphasis has been

\footnotetext{
${ }^{1}$ Pym (2016: 247) prefers the term 'start text' to the fairly well established 'source text' because nowadays translators work not just from a single text but also from glossaries, translation memories and machine translation output, and any of those resources could provide the 'source' for a translation solution. The role of the initial text is thus relativized; it is no more than the starting point for the translation process.
}

XLinguae Journal, Volume 10 Issue 3, June 2017, ISSN 1337-8384 
mainly on Western European countries, however, with very little work done within the Central-European context such as Slovakia.

Written in 1991 by Peter Pišt'anek, the novel depicts a rather controversial period in history for the post-communist Slovakia after the so-called Velvet Revolution and the break-up of the Soviet Union. As a result, the book is suffused with a good many culture-bound items symptomatic of the by-gone socialist era in the former Czechoslovakia including material culture realia, names of institutions, proper names, colloquial expressions as well as language of the minorities. The English translation of the Slovak best-seller was not published until 2007 when Peter Petro as English translator of Slovak origin had to fulfil his role as a cultural mediator confronting the issues of culture-transfer upon transplanting the novel in question into a geographically, culturally and historically different space.

\section{Translation as intercultural communication}

The term 'culture', however widely used, may be defined in numerous ways. Rakšányiová (2005: 9) mentions as many as 169 definitions of the term by Beheydt. For my purpose reported here, the definition by Newmark (1988: 94) as "the way of life and its manifestations that are peculiar to a community that uses a particular language as its means of expression" has been utilized in this paper.

Over the past two decades or so, translation has been placed at the core of intercultural aspects so that the study of the translation goes along with the cultural studies. Subsequently, cultural aspects of translation have emerged into theories about cultural translation, about its very existence in terms of a specific community's cultural identity. Tracing the beginnings of cultural dealings in translation studies, Nida concluded in his prominent 1964 work that differences between cultures may cause more severe complications for the translator than dissimilarities in language structures. The relationship between language and culture was first formally formulated by Humboldt who saw language as the expression of culture of its speakers, who understand and perceive the world through language. Considering Sapir and Whorf's hypothesis, culture and its attendant decoding and can also affect understanding of the message (Maasoum and Davtalab, 2011: 1769). Wisely enough, Larson (1997: 163) admits that due to differences in geography, customs, beliefs, world-views, and various other factors there will always be concepts in the SL which do not have lexical equivalents in the TL or they cover only some aspects in the receptor culture and thus are not entirely equivalent. This phenomenon is referred to by Gambier (2007: 11) as "semantic void or lexical gap."

In order to rule out negative connotations and associations of the word material, the knowledge of intercultural differences is required for a deft translator, aside from linguistic, sociolinguistic, discourse, strategic or other competences. The intercultural competence, which stands for the translator's ability to interact with cultures, their history, traditions and customs, and to be aware of the impact of the cultural elements on translation and intercultural communication, requires having intercultural awareness. Based on Baker's approach, this is "a conscious understanding of the role culturally based forms, practices and frames of reference can have in intercultural communication, and an ability to put these conceptions into practice in a flexible and context specific manner in real time communication" (qtd. in Lee, 2015: 384). This means that intercultural competence and intercultural awareness can be considered as two key qualities required from the translator as a mediator between cultures.

\section{The concept of culture-bound items}

Culture-bound items (hereafter abbreviated as 'CBIs') refer to those concepts and references of the lexical items which are peculiar to a given cultural community. According to Florin (1993: 123) they are words which denote objects and 
concepts characteristic of the way of life, culture, social and historical development of one nation and alien to another.

Despite the fact that that the notion of CBIs has been quite widely elaborated (e.g. by Newmark 1988; Baker 1992 or Lungu Badea 2004), there seems to be the lack of terminological homogeneity in the concept. Cultural words (Newmark 1988), culture-specific concepts (Baker 1992), culture-specific items (Schäffner and Wiesemann 2001), culture-bound terms (Harvey 2000), cultural implications (James 2002), cultural references (Lee 2015), realia (Robinson 2012), culturems (Lungu Badea 2004), linguo-culturems (Sipko 2011) or culturally-marked items (Shiryaeva and Lungu Badea 2014) all share the same denotative semantics. I understand CBIs as special context-dependent lexical items with a deep ethno-cultural meaning and unique connotations which pose problems for translation from the source culture (SC) into the target culture (TC). A special property of CBIs is that they are contextdependent since any sort of text element can become a culture-specific item in so far as it carries a connotative meaning in the SC (see Terestyényi, 2011: 14).

Newmark (1988: 95) lists among CBIs ecology (flora, fauna, winds, plains, hills); material culture (food, clothes, houses and towns, transport); social culture (work and leisure); organizations, customs, activities, procedures, concepts - political, administrative, religious and artistic; gestures and habits. Gambier (2007) asserts that CBIs connote different aspects of life such as education, history, art, institutions, legal systems, units of measurement, place names, foods and drinks, sports and national pastimes. A useful classification of CBIs is used by Vlahov and Florin (1980) (qtd. in Terestyényi, 2011:13), although they use the somewhat oldish term "realia", as they organize them along geographical, ethnographic, artistic and cultural, ethnic and socio-political lines.

\section{Strategies for the translation of culture-bound items}

The translation of CBIs is a controversial undertaking because a single word or phrase may be translated in different ways by different translators. Moreover, when translating CBIs conveying the meaning takes priority over the form. Considering interlingual translation, Popovič (1975: 188) perceives the tension between the culture of the original and that of the translation, which can be materialized on the axis of binary oppositions as 'we - they' and 'ours- foreign', and speaks of the following trichotomy:

(a) $\mathrm{C} 1>\mathrm{C} 2$ - activity of the external conditions (or culture) overcomes the activity of the inner conditions; then foreignization is present according to Venuti (corresponding in Slovak terminology to exoticization)

(b) $\mathrm{C} 2>\mathrm{C} 1$ - activity of the inner conditions (culture) overcomes the activity of the external conditions; then domestication is present according to Venuti (in Slovak terminology naturalization)

(c) $\mathrm{C} 1=\mathrm{C} 2-$ the tension between the culture of the original and the culture of the translation is counterbalanced; so-called creolization takes place, which stands for the mixing of elements from both cultures

As can be seen, Popovič takes into account the inter-relation of cultures. He was well ahead of his time because he had been dealing with the role of culture in intercultural communication long before the contemporary cultural and translation studies started to draw attention to it.

Furthermore, there are two extra-textual factors which have an impact on the translation of a text containing CBIs, these being first and foremost the purpose of the 
text and second a target reader. As to the former, it is determinative if a text is literary or non-literary since technical papers, for example, seem to contain far fewer CBIs than cultural or historical texts. The intention of the translator for the preservation or replacement of CBIs may differ according to the text type and its purpose. As to the latter, the translator, in the same way as the ST author, has to consider the person for whom the text is written or translated, i.e. the potential (ideal) reader. James (2002) in her paper distinguishes the ST ideal reader and the TT ideal reader. For both of them, we can assume certain knowledge, facts, experiences, prejudices, and also cultural knowledge. Cultural knowledge can differ in the position of the ST and the TT ideal reader. As Coulthard claims (James, 2002), "the translator's first and major difficulty is the construction of a new ideal reader who, even if he has the same academic, professional and intellectual level as the original reader, will have significantly different textual expectations and cultural knowledge". Hence, the translator has to firstly decode and analyse the ST potential reader with his knowledge, beliefs, social and cultural background, so that he can reconstruct the TT potential reader and thus state the purpose of the text. As the research by Lee (2015: 387) confirms, the translator pays more attention to CBIs and their proper transfer into the TT when considering the target audience.

To date, strategies ${ }^{2}$ for the translation of CBIs have been proposed by many. Both Newmark (1988) and Harvey (2000) think of functional equivalents (requiring the use of a culture-neutral words), formal equivalents, transcriptions or borrowings and using descriptive equivalents or self-explanatory translations as prominent solutions. Overall, Newmark (1988) proposes two opposing methods: transference - a strategy when a SL word is transferred into a TL in its original form which gives colour to the text, e.g. keeping cultural names and concepts; and componential analysis which excludes the culture and highlights the message. Katan (2014) suggests three solutions: (1) borrowing or adaptation, (2) omission and (3) creating one's own expression. Klaudy (2003) adduces generalisation: the SL unit of a more specific meaning is replaced by a TL unit with a more general meaning; circumlocution: that is explanation, the use of many words to say something that could be said in one word or in a few words; addition: new meaningful elements, that cannot be found in the original, appear in the translation to supply background knowledge for the TL readers; and omission: dropping meaningful lexical elements of the SL text. Using a somewhat detached view, other theorists (e.g. Hervey and Higgins, 1992) argue that the translation strategies for CBIs vary between the two poles of exoticization and cultural transplantation (or naturalization). Having CBIs in mind, this paper employs Pym's latest model of translation solutions (2016), and in this rests its contribution to contemporary translation studies research focusing on cultural translation.

Pym's new typology of translation solutions invites translators to widen their range of possible actions, proposing more intervention and invention. In his own words, Pym has given weight to the copying of words, which means drawing on and presenting the foreign; he has emphasized the role of textual density as a factor which can be worked on by the translator when appropriate and he has permitted that translation can involve changes in content, moving beyond the conceptual limits of narrow equivalence (Pym, 2016: 244). Pym's proposed new typology of translation solution types is given in Table 1 .

\footnotetext{
${ }^{2}$ Also often called "procedures", "techniques" or lately "solutions" by Pym (2016). On the distinction between them, see
} Gibová (2012: 27-29). 
2016: 220)

Table 1: A typology of translation solution types (source: Pym,

\begin{tabular}{|c|c|c|}
\hline \multirow{6}{*}{ Copying } & \multirow{3}{*}{ Copying Words } & Copying Sounds \\
\hline & & Copying Morphology \\
\hline & & Copying Script .... \\
\hline & \multirow{3}{*}{ Copying Structure } & Copying Prosodic Features \\
\hline & & Copying Fixed Phrases \\
\hline & & Copying Text Structure ... \\
\hline \multirow{11}{*}{$\begin{array}{l}\text { Expression } \\
\text { Change }\end{array}$} & \multirow{3}{*}{ Perspective Change } & Changing Sentence Focus \\
\hline & & Changing Semantic Focus \\
\hline & & Changing Voice ... \\
\hline & \multirow{4}{*}{ Density Change } & Generalization/Specification \\
\hline & & Explicitation/Implicitation \\
\hline & & Multiple Translation \\
\hline & & Resegmentation ... \\
\hline & \multirow[b]{2}{*}{ Compensation } & New Level of Expression \\
\hline & & $\begin{array}{l}\text { New Place in Text (notes, paratexts) } \\
\ldots\end{array}$ \\
\hline & \multirow[b]{2}{*}{ Cultual Correspondence } & Corresponding Idioms \\
\hline & & $\begin{array}{l}\text { Corresponding } \quad \text { Culture-Specific } \\
\text { Items ... }\end{array}$ \\
\hline \multirow{3}{*}{$\begin{array}{l}\text { Content } \\
\text { Change }\end{array}$} & \multirow{3}{*}{ Text Tailoring } & Correction/Censorship/Updating \\
\hline & & Omission of Content \\
\hline & & Addition of Content \\
\hline
\end{tabular}

The translation solution of 'Copying' is based on using minimal linguistic units which are meaningful when used either alone (copying words) or in larger syntactic patterns (copying structure). In case of the 'Copying Words' there are three main linguistic levels involved: phonetics (sounds), the meaning-expressing units (morphemes) and the written form (scripts). 'Copying Structure' comprises copying prosodic features (rhyme, rhythm, alliteration), fixed phrases (syntax, idioms, common expressions) and text structure (paragraph and major units of text organization) and sails close to word-for-word literalism, which is reminiscent of Newmark's literal translation. 'Perspective Change' appears to be another name for classical modulation based on seeing the same object from a different angle. It involves changing sentence focus (all the non-obligatory sentence-level syntactic transformations), changing semantic focus (change due to the choice of different values) and changing voice (changes in register). 'Density Change' concerns how much text is used so as to convey a given set of information. The main sub-types are the following: generalization/specification (changing the degree of specificity), explicitation/implicitation (showing or hiding implicit information), multiple translation and resegmentation (changing sentence or clause breaks), which Newmark dubs 'recasting sentences'. Compensation is understood as placing the solution in a new textual location and/or at a new linguistic level. However, one could argue that this is not a proper solution type per se since it merely concerns the place or level where other types are used. Cultural Correspondence includes translation based on

XLinguae Journal, Volume 10 Issue 3, June 2017, ISSN 1337-8384 
using corresponding idioms and corresponding culture-specific items (e.g. units of measurement, currency and forms of address). Lastly, Text Tailoring (or Content Change) recognizes that there are situations where translators legitimately alter what is actually said in the text; they may correct mistakes, delete significant stretches of material that is not pertinent to the purpose of the new text or conversely, add new information which enhances that purpose. The main sub-types of text tailoring are correction/censorship/updating, omission of content and addition of content (based on Pym, 2016: 221- 232).

\section{Data \& methodology}

The paper draws on the premise that when dealing with cultural asymmetries between languages involved in translation cultural transplantation is inevitable. This supports the interpretation of translation as an essentially cultural practice (see Hermans, 2007). The overall aim of the research is to examine translation techniques used for the translation of Slovak CBIs sourced from the novel Rivers of Babylon based on Pym's cutting-edge model of translation solutions (2016). The partial aim is also to research the extent to which the local colour of the Slovak start text has been preserved in the English literary translation. The research puts to the test the following hypothesis: drawing on the dominating Anglo-American translation culture preference supporting ethnocentric violence (see Venuti, 1995: 20) and cultural imperialism (Wright, 2016: 85), it may be assumed that the overall translation method is that of domestication. Accordingly, the English translation prefers solutions which seem to neutralize the Slovak culture-bound items in order to make the TT more comprehensible for the ideal TT reader.

As regards the corpus underlying the present research, $130 \mathrm{CBIs}$ have been collected from the novel under investigation. Simultaneously, their English equivalents have been looked up in the translation by the method of a contrastive text analysis. The inclusion criteria for the selected CBIs are based on Newmark's categories of cultural words, i.e. expressions denoting material culture (towns, buildings, institutions, food, clothes), social culture (especially of a socio-political nature), names, gestures, habits and organizations. The corpus also includes slangy and dialectal expressions and lexis typical for ethnic minorities. The CBIs have been carefully excerpted in such a manner so that they faithfully reflect the local colour of the (post)-socialist period in Slovakia.

After the preliminary corpus analysis, etymology and usage of the excerpted CBIs have been investigated in the Slovak National e-corpus at http://slovniky.juls.savba.sk and multifarious e-dictionaries. ${ }^{3}$ The comparative corpus analysis has been performed with the aim of substantiating the start text - target text unit pair into a particular translation solution based on Pym's model (2016). The collected CBIs have been organized into pertinent categories, taking into account also combinations with another translation solution type (couplets). In case of combinations, each translation solution has been counted in the final quantitative analysis in order to map out the incidence of the translation solutions used. The chosen instances of CBIs in the following section are not meant to capture the culturally-marked lexis of the novel in its entirety (which would be nonetheless impossible due to this paper's limited extent); they have been selected to sketch its salient traits.

\section{Analysis and discussion 5.1 Copying: Copying Words}

${ }^{3}$ http://freethesaurus.com, http://idioms.thefreedictionary.com and http://macmillandictionary.com. 
The norm in some cultures is to introduce names by imitating foreign sounds and morphology, applying what Newmark (1988) calls 'transference' or 'naturalization' depending on the extent of the adaptation into the TC and Pym (2016) 'copying'. When translators copy sounds in this fashion, their actions may be the first steps in a process by which a new term or phrase enters a language. In this way, for illustration, the English word football becomes Slovak futbal. The argument in favour of copying words is that it shows respect for the source culture. On the other hand, the argument against it could be that the translator's job, as Newmark puts it (1988: 82), is to translate, to explain and not to copy.

Throughout the novel, characters' proper names, geographical and topographical names, street names and addresses, names of public and nationalised institutions, shops and brand names have been copied. In this way, proper names such as Donáth, Edre, Eržika, Rácz, Kǐ̌̌s, Berki, Ďula, Š́poš and many others are scattered in the English translation. However, in order to make it easier for the English reader, the translator provides a short list of characters' names pronunciation at the outset of the novel. According to Pym (2016) such a translation solution stands for Text Tailoring taking the form of the addition of content. Some Slovak names have been transferred into English with an adaptation at a phonetic level, e.g. Ribana Salajová (where the -ová suffix stands for the most Slovak female surnames) appears as Ribana Salay, the name of the West-Slovak region Záhorie is copied as Zahorie or Blumentálsky kostol corresponds to the Blumenthal church. These solutions stand closer to naturalization when the full adaptation of a word's phonetical and morphological levels takes place.

To illustrate further peculiarities of Copying Words in the novel, three CBIs have been selected, all contextualized in Table 2.

Table 2: Selected CBIs as Copying Words

\begin{tabular}{|c|c|}
\hline Slovak start text & English target text \\
\hline $\begin{array}{l}\mathrm{V} \text { noci z piatka na sobotu si do } \\
\text { hotela Ambassador prichádzajú } \\
\text { vyhodit' z kopýtka juhoslovanskí } \\
\text { gastarbeitri, pracujúci vo Viedni. } \\
\text { (p. 94) }\end{array}$ & $\begin{array}{l}\text { On Friday nights Yugoslav Gastarbeiter } \\
\text { from Vienna come to let off steam. (p. } \\
76 \text { ) }\end{array}$ \\
\hline $\begin{array}{l}\text { Potrebujeme nacvičit' nové číslo. } \\
\text { Istotne to poznáte, teraz to všade } \\
\text { letí. Pampatdžem. Tak sa to volá. } \\
\text { (p. 71) }\end{array}$ & $\begin{array}{l}\text { "We have to rehearse a new number. You } \\
\text { must have heard it; it's playing } \\
\text { everywhere: Pampa Jam. That's the } \\
\text { name." (p. 58) }\end{array}$ \\
\hline $\begin{array}{l}\text { Rácz ho v kotolni čaká s hŕbou valút } \\
\text { na stole. Sadni si, povie Urbanovi. } \\
\text { Dáš si niečo? Whisky hivaš regál? } \\
\text { Cigarety benson et hed'eš? ... (p. } \\
\text { 88) }\end{array}$ & $\begin{array}{l}\text { Rácz is waiting for him in the boiler- } \\
\text { room with a pile of foreign currency on } \\
\text { the table. "Will you have something? } \\
\text { Whisky Heevash Reygahl? Benson and } \\
\text { Hegyesh cigarettes? ... (p. 71) }\end{array}$ \\
\hline
\end{tabular}

Firstly, there is Slovak CBI gastarbeitri (although being a German borrowing by descent), which denotes foreign workers who work in developed countries for a lower salary than native citizens; e.g. Slovaks working in Germany and Austria, but also Romani, Turkish and Ukrainian workers. This lexeme is transferred into English with a change in a capital letter, which relates to English grammar, where members of nationalities/minorities or groups are capitalized. Secondly, the name of

XLinguae Journal, Volume 10 Issue 3, June 2017, ISSN 1337-8384 
the cabaret show Pampatdžem is most likely made up by the author as no cabaret show called Pampatdžem exists. Using his creativity, the translator copied the name with a play on words translating ,džem "e marking it off from the determining word. Thirdly, the last example in Table 2 is rather specific for it depicts Rácz's intellect. Pišt'anek's main character is characterized by behaviour and language of an uneducated person. His Hungarian nationality is also present in some of his expressions. He offers Video Urban, who is another character in the novel, whisky and cigarettes which he has received from rich customers as an exchange for heating in their rooms, but he has no idea about their brand or correct pronunciation. Therefore, Pišt'anek lets Rácz pronounce the alcohol and cigarettes names as hivaš regál and benson et hed'eš, respectively (where "et" points out to his Hungarian nationality and means "and"). The English translation is intriguing since the translator decided not to use an English name of whisky (Chivas Regal) and cigarettes (Benson \& Hedges), but transferred the CBIs with a phonetic adaptation, achieving playful sounds. The reason for such a translation solution is probably the aim of the translator to emphasise Rácz's s ignorance, his nationality and ethnicity. This can be confirmed by the following statement where Petro (2014) comments on his translation:

Rácz comes from southern Slovakia, from the village with most probably Hungarian citizens. Even if it is not mentioned in the text, it is obvious from the way how Rácz is talking to his friends. So how to inform the English reader that Rácz is a member of national minority? [...] When I'm reading the novel in Slovak, I do not speculate whether Rácz is normal. I accept that he is obtuse due to his background, language mastery or education; and I see him as a simple man who is not such an idiot to put two and two together ${ }^{4}$.

With respect to Copying Words, a noteworthy tendency in the corpus is using what I call (with reference to Pym 2016 and Newmark 1988) 'translation solution couplets'. This means that not only one translation solution is used for CBIs, but it may be complemented by another translation solution, forming a couplet. The corpus analysis has revealed that Copying Words has often been combined with Density Change, which may be looked upon as a blend of multiple translation and explicitation, e.g. Mototechna, as a well-known name of a shop in the former Czechoslovakia where car parts used to be sold, is rendered as Mototechna car parts shop. Similarly, the socialist famous shop with foreign goods Tuzex, where buyers had to pay with special foreign currency vouchers called "bony" exchanged for dollars or marks in a bank, is translated also descriptively as Tuzex, the foreign-currency store. In earlier translation technique typologies, the above would most likely correspond to e.g. Newmark's descriptive equivalents. The benefit of these translation solution couplets is that they not only keep the local colour, but also make the CBIs comprehensible for the target reader.

\subsection{Copying: Copying Structure}

Although in minority, there are several CBIs throughout the novel whose translation into English is based on copying the start text's structure in terms of its fixed phrases, more precisely common expressions. The translator usually tends to copying if there is semantically and pragmatically proper equivalent for it. For example, the proper name of a shop Domáce potreby is adequately translated as household goods shop. This translation solution, which is according to Pym's interpretation based on copying the source structure, is very much redolent of Vinay and Darbelnet's calque or Newmark's literal translation. This is suitable when the words not only refer to the same concept, but have similar associations, too. Here, the target reader clearly understands the concept of a shop where household products can be purchased. Similarly, the name of the institution Fond národného majetku is

${ }^{4}$ translation by author 
copied into English literally as the National Property Fund. To justify such a translation solution, it is claimed that the names of international organizations should be transferred whereas in other cases they should be translated creatively (see Newmark 1988). Interestingly enough, a misinterpretation has been made on the part of the translator in case of the name of the restaurant Pohorelec which has been rendered into English as the Highlander Restaurant. Here, copying the source structure fails semantically. In Slovak, the lexeme pohorelec is used to refer to a person whose house has been burnt down ${ }^{5}$, not to someone who comes from the Scottish Highlands, which is denotatively implied by the English translation of the head noun's pre-modifier when semantically decomposed.

\subsection{Expression Change: Cultural Correspondence}

As has been confirmed by the analysis, not all CBIs have an equivalent in the TL because sometimes the object of denotation does not exist in the TC. In the corpus there are several CBIs which have been substituted with attendant cultural equivalents although their semantic equivalence may not be exactly the same. What is, however, important for the translation solution of Cultural Correspondence is that it has a much greater pragmatic impact in comparison to culturally neutral terms which would detract from the cultural aspect of translation.

For example, the Slovak culturally-marked lexeme serepetičky, which stands for something of little importance or value, best corresponds to English little trifles, having a somewhat archaic veneer. Next, hruškovica, is a well-known strong alcoholic beverage distilled from pear in the Slovak environment. If the translator were to copy its structure, this would correspond most likely to pear spirit. However, the translator opted for using alcohol which is more typical for the English culture, i.e. pear brandy which is produced by distilling wine.

The translation solution of cultural correspondence also encompasses the case of using corresponding cultural idioms, e.g. neminút' ani vindru (where the colloquial word vindra refers to coins of low value) is translated as not spending a penny (where the English reader understands the message right away). Similarly, the cultural idiom tvrdýlmrtvy ako štolverk is translated as dead as a doornail, which uses a completely different imagery. As regards Slovak etymology, štolverk refers to a hard caramel candy invented by Stollwerk ${ }^{6}$. On the English front, the idiom dead as a doornail refers to a nail which has been bent when building doors using wood boards and hand forged nails and is said to be "dead" in this way ${ }^{7}$. In the novel, both idioms refer to Hurrenson's stiff body who died while being involved in an orgy after taking drugs. In the English translation, based on the chosen cultural idiom, the reader is able to decode the message that Hurrenson has passed away. Selected examples of CBIs based on Cultural Correspondence are summarised in Table 3.

Table 3: Selected CBIs based on Cultural Correspondence

\begin{tabular}{|l|l|}
\hline \multicolumn{1}{|c|}{ Slovak start text } & \multicolumn{1}{|c|}{ English target text } \\
\hline $\begin{array}{l}\text { Takže on, Rácz, nebude d'aleko od } \\
\text { pravdy, ked' povie, že vedúci } \\
\text { reštaurácie ovláda všetky tie } \\
\text { serepetičky! (p. 248) }\end{array}$ & $\begin{array}{l}\text { he said that the restaurant manager } \\
\text { knows all about those little trifles. (p. } \\
195)\end{array}$ \\
\hline
\end{tabular}

${ }^{5}$ www.slovniky.juls.savba.sk

${ }^{6}$ www.slovniky.juls.savba.sk

${ }^{7}$ See www.en.wiktionary.org for more information on the idiom's etymology.

XLinguae Journal, Volume 10 Issue 3, June 2017, ISSN 1337-8384 


\begin{tabular}{|l|l|}
\hline $\begin{array}{l}\text { Na stôl položí poloplnú fl'ašu } \\
\text { hruškovice a naleje. (p. 171) }\end{array}$ & $\begin{array}{l}\text { He puts a half-empty bottle of pear } \\
\text { brandy on the table and pours drinks. } \\
\text { (p.135) }\end{array}$ \\
\hline $\begin{array}{l}\text { Na taxík Hurrenson neminul ani } \\
\text { vindru; on, Urban, ho všade vozil. (p. } \\
44)\end{array}$ & $\begin{array}{l}\text { Hurrenson didn't spend a penny on } \\
\text { taxis, as Urban drove him everywhere. } \\
\text { (p. 36) }\end{array}$ \\
\hline $\begin{array}{l}\text { Budú ho prezerat' a zistia, že fetoval. } \\
\text { A sme v riti! Aj tak je tvrdý ako } \\
\text { stolverk. (p. 239) }\end{array}$ & $\begin{array}{l}\text { They'll examine him and find out that } \\
\text { he's taken drugs. Then we're screwed. } \\
\text { He's dead as a doornail, anyway.(p. } \\
188)\end{array}$ \\
\hline
\end{tabular}

\subsection{Expression Change: Density Change}

Based on the above, it may be presumed that it may be demanding for the translator to find an appropriate cultural correspondence in translation since their knowledge of pertinent CBIs need not be complete. This being the case, they must have recourse to other translation solutions, e.g. Density Change.

Density Change covers in Pym's understanding a rather heteregenous category subsuming generalization/specification, explicitation/implicitation, multiple translation and resegmentation. It is based on deculturalising a CBI by using neutral, cultural-free words. In my view, Density Change appears, from a terminological angle, a useful translation solution because in traditional translation technique typologies there has always been a fine line between functional and descriptive equivalent (see e.g. Newmark 1988). For example, the Slovak CBI Prior refers a shopping centre in socialist era where Slovaks queued for long hours waiting for clothes or fruit from abroad. In the English translation under analysis, it was translated rather generally as shop, where the cultural conceptualization is reduced only to the concept of a mere place where things are sold. In earlier translational interpretations, it would be debatable if this were the case of a functional or descriptive equivalent. With Density Change, and more specifically, generalization, however, this problem is overcome.

Overall, a great many CBIs in the novel have been translated by means of generalization, which has contributed to decreasing the local colour of the start text and its de-foreignization. Consider the following selected lexical pairs: emdéžetka - $a$ textile factory, anton - a police van, solvina - degreaser and krabička marsiek - a pack of cigarettes etc. Emdéžetka is an abbreviation for a factory in Bratislava závody MDŽ, which would correspond to International Women's Day Factory in English translation. Even for the young Slovak generation, however, this name is almost unknown, and this is where generalization on the part of the translator seems justified. In addition, the denomination závody $M D Z ̌$ carries in itself a special socialist flavour, which is lost in the generalized English translation. Moving on to the next example, anton is a colloquial denomination for a police van named after a Portuguese Catholic priest Saint Anthony of Padua who was famous for helping the police a lot. ${ }^{8}$ As the potential English reader cannot usually be expected to be familiar with Slovak culture, again, generalization on the part of the translator proves wise. Further, solvina refers to degreaser sold in the former Czechoslovakia by the firm Zenit and krabička marsiek refers to a pack of cigarettes of the brand Mars, which enjoyed popularity among Slovak smokers. Although these lexical pairs serve to confirm the translator's tendency towards generalization, it could be objected that in some cases Copying could have been used along with Density Change, resulting in

${ }^{8}$ www.slovniky.juls.savba.sk 
TT formations such as solvina degreaser or a pack of Mars cigarettes, which would preserve both the local colour and provide an explanation at the same time.

A most interesting batch of CBIs in the corpus relates to socio-political lexemes concerning the illegal business of changing money, which was a fairly popular practice in socialist Czechoslovakia. The whole set of lexemes is linked to this, e.g. vekslák - currency dealer, veksláčenie - money-changing business, veksel' money-changing, kupóny - the sale of vouchers. In marked contrast to the CBIs discussed previously, the above lexemes have been translated using explicitation. The same applies to a special Slovak cultural-bound lexical item bony, referring to the currency that was used in socialist Tuzex shops (discussed in section 5.1) and is rendered as foreign currency vouchers. With selected examples of explicitation like these, more elaborate and explicit TT lexical segments appear, as documented in Table 4.

(generalization/explicitation)

Table 4: Selected CBIs based on Density Change

\begin{tabular}{|c|c|c|}
\hline Slovak start text & English target text & \\
\hline $\begin{array}{l}\text { Nie, nie! povie. Takú } \\
\text { už nikdy nezoženiem! } \\
\text { jediný raz boli v } \\
\text { Priore a odvtedy už } \\
\text { nie! (p. 277) }\end{array}$ & $\begin{array}{l}\text { "No, no," he says, "I'll never find } \\
\text { another one like this. They only } \\
\text { got them in the shop once and } \\
\text { then they were sold out." (p. 218) }\end{array}$ & generalization \\
\hline $\begin{array}{l}\text { Edite by sa zasa nikdy } \\
\text { ani len nebolo } \\
\text { prisnilo, že sa raz } \\
\text { stane tanečnicou z } \\
\text { povolania. Navíjala } \\
\text { cievky v emdéžetke. } \\
\text { Po večeroch tancovala } \\
\text { vo folklórnom súbore. } \\
\text { (p. 31) }\end{array}$ & $\begin{array}{l}\text { Edita would not have even dreamt } \\
\text { of becoming a professional } \\
\text { dancer. She used to work the } \\
\text { spools in a textile factory and in } \\
\text { the evenings she danced in a folk } \\
\text { group. (p. 25) }\end{array}$ & generalization \\
\hline $\begin{array}{l}\text { Nespúšt’ajúc pohl'ad z } \\
\text { policajtov, šacujúcich } \\
\text { cigánov a vekslákov a } \\
\text { nakladajúcich ich do } \\
\text { antona, hmatká rukou } \\
\text { po stene. (p. 25) }\end{array}$ & $\begin{array}{l}\text { Keeping the policemen in sight as } \\
\text { they search the gypsies and } \\
\text { currency dealers and bundle } \\
\text { them into a police van, he gropes } \\
\text { his way along the wall. (p. 20) }\end{array}$ & $\begin{array}{l}\text { explicitation } \\
\text { generalization }\end{array}$ \\
\hline $\begin{array}{l}\text { Nemáme solvínu, } \\
\text { prihovorí sa Donáth } \\
\text { riaditel'ovi, onedlho } \\
\text { budem robit' tú... } \\
\text { prezervatívnu } \\
\text { prehliadku. (p. 34) }\end{array}$ & $\begin{array}{l}\text { "We don't have any degreaser," } \\
\text { Donáth approaches the manager, } \\
\text { "and soon we'll be doing the, you } \\
\text { know, preventive check-up..." (p. } \\
\text { 28) }\end{array}$ & generalization \\
\hline $\begin{array}{l}\text { Vo vrecku ho omína } \\
\text { tisícmarkovka a zopár } \\
\text { stoviek bude musiet' } \\
\text { ešte vyvekslovat', ... }\end{array}$ & $\begin{array}{l}\text { He has in his pocket a thousand- } \\
\text { deutschmark bank note and he } \\
\text { needs to hustle up a few more } \\
\text { hundred marks, by changing }\end{array}$ & explicitation \\
\hline
\end{tabular}

XLinguae Journal, Volume 10 Issue 3, June 2017, ISSN 1337-8384 


\begin{tabular}{|l|l|l|}
\hline (p. 22) & $\begin{array}{l}\text { money illegally for tourists, } \ldots \\
(\mathrm{p} .18)\end{array}$ & \\
\hline
\end{tabular}

\subsection{Expression Change: Perspective Change}

Besides all the translation solutions which have been discussed above, the corpus analysis has also revealed instances of CBIs whose translation is affected by Perspective Change, more specifically by changing voice. According to Pym (2016: 225 ) this comprises not only changing voice from the passive into active (as in classical modulation), but also changes in register. Thus, there are CBIs whose transplantation into the TC has been marked by translation-neutralization into noncolloquial and non-expressive words. For instance, the Slovak culture-bound lexical units šilasy, being a slang word for Austrian schillings and makovice, being a slang word for German marks, have been attenuated in the English translation as schillings and marks, respectively. In a similar fashion, a frequent Slovak socio-political CBI bol'sevici, which used to be a derogatory word for communist followers, appears in the studied English translation as communists. Such translation solutions are marked by the so-called 'attenuation of expression', resulting in its stylistic weakening, as Popovič (1975) of the Nitra School of translation would call it.

Although changing sentence of focus has not been ascertained in the CBI corpus, one interesting occurrence of changing semantic focus has been detected by the analysis. This concerns the evocative character's proper name Špáršvajn who is a mean car park keeper in the novel and always wears a bum bag with his money. Since the Slovak suffix - ̌́vajn may be presumed to have been borrowed from the German word Schwein standing for swine with mostly negative connotations, the word root špár- is reminiscent of the German verb sparen, meaning saving up money. The English translation solution taking the form of Piggybank is based on the choice of a different value, i.e. referring to a small pig-shaped container which is used for saving money by children. In this way, the CBI's semantic focus has been changed when reporting the Slovak culture to the English culture.

\subsection{Summary of findings}

After the interpretation of translation solutions, a quantitative evaluation of the data has been made and is represented in Charts 1 and 2. As it follows from the research, the dominant translation solution for CBIs in the novel under analysis is Density Change, represented by $40.77 \%$, followed by Copying Words (26.92\%) and combination of Copying Words and Density Change (13.08\%). As regards the Copying Words, more than a half of all copying translation solutions (i.e. 54.29\%) were constituted by transferring proper names, which may slightly detract from the overall significance of Copying for the non-equivalent lexis.

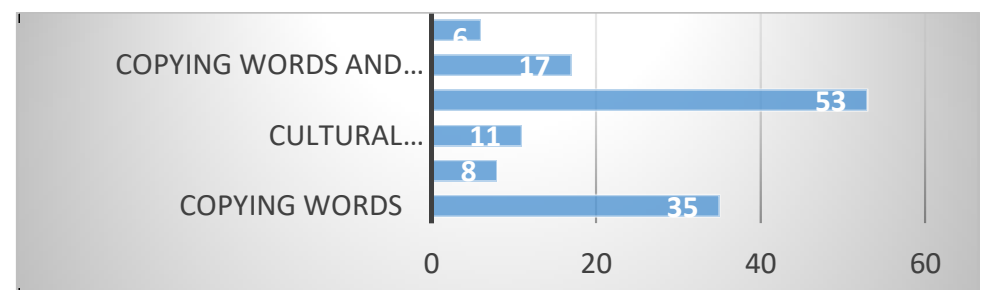

frequency)

Chart 1: Translation solutions for the analysed CBIs (absolute 

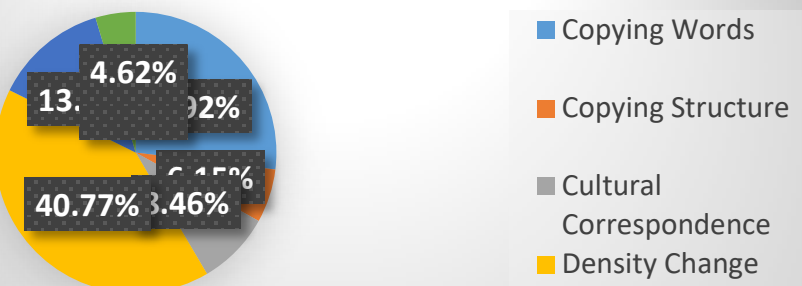

Chart 2: Translation solutions for the analysed CBIs (relative frequency)

The translation solutions have also been grouped into those which represent foreignization (or exoticization in Slovak TS terminology) and domestication (or naturalization) to confirm/disprove the research hypothesis. Density Change, Cultural Correspondence, Perspective Change represent in their essence domestication translation methods while Copying Words and Copying Structure are based on the foreignization method. The combination of Copying Words and Density Change is a mixture of foreignization and domestication, so it represents creolization on the part of the translator. The corpus analysis results are displayed in Charts 3 and 4 , respectively.

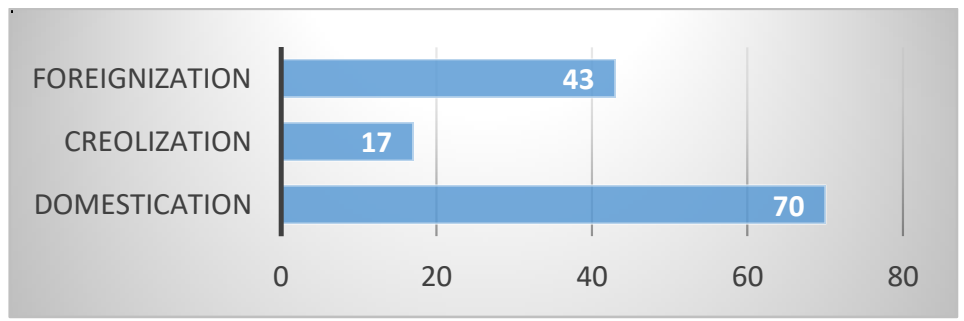

Chart 3: The dominant translation method for the analysed CBIs (absolute frequency)

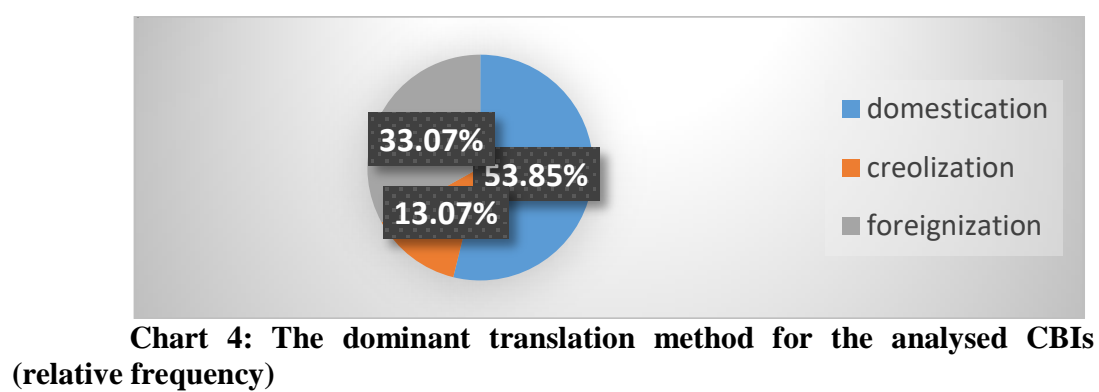

XLinguae Journal, Volume 10 Issue 3, June 2017, ISSN 1337-8384 
As can be seen, domestication is the major translation method used for the translation of the analysed CBIs and represents $53.85 \%$ of all translation solutions. Foreignization has been applied in $33.07 \%$ of translation solutions whereas creolization as a combination of foreignization and domestication has been used in $13.07 \%$.

\section{Conclusions and implications}

Several conclusions may be drawn with regard to the translation of CBIs in the examined novel. Firstly, Copying Words serves to maintain the local colour of the Slovak CBIs. This translation solution transfers CBIs from the original into the target culture and is sometimes accompanied by phonetic adaptation into the TL. If this translation solution were preponderant for the translation of CBIs, this would have resulted in a foreignizing effect in the TT. The benefit of the foreignizing approach, however, could be moving away from the current Anglo-American cultural imperialism which is supportive of the domesticating approach in translation. Copying Words has been chiefly used for transferring proper names, colloquial and minorities' expressions in the novel. Copying Words has sometimes been combined with Density Change, which represents a mixture of foreignization and domestication.

Secondly, Density Change (especially generalization and explicitation) together with Cultural Correspondence and Perspective Change, have domesticated the translation, because they have brought more general and culturally-neutral expression to the TT. The frequent use of generalizing translation solutions for CBIs could have been caused by the fact that Peter Petro, who provided the English translation, is Slovak so he may not have been familiar with all English CBIs which would substitute the Slovak ones deftly. On the other hand, if there had been an English translator, who would have been capable of supplying culturally top-notch English equivalents, he would have in all probability struggled with slangy or dialectal Slovak CBIs.

Thirdly, it may be summed up that the major translation method for the translation of the analysed CBIs is domestication, which, however, did not keep the local colour of the Slovak start text in many cases. The Slovak CBIs which have been domesticated have been replaced with the English CBIs which are more familiar to the target culture and its readership. This means that the role of the target reader has been principal for the translator. Even if he has on the whole neutralized the cultural colour of the novel, his chosen translation method has not seriously hampered the novel's message and context and was considerate of the English reader. On a wider level, the chosen translation method also implies the importance and function of CBIs in the text.

Fourthly, based on the research it has been shown that the status of the foreign has not been integrated in the English translation overwhelmingly. Thus, it may be argued that the research hypothesis has been corroborated. Overall, the novel has been translated in a transparent and fluent style keeping domestication superior to foreignization. The Slovak start text has been reduced to the TL cultural values. This is, however, in line with Anglo-American ethno-centric translational violence, where "a translation is an appropriation, a text [a TC] makes [its] own to a greater or lesser degree so as to avoid the full alienation of engagement with the foreign" (Wright, 2016: 85). Domestication in the analysed translation reflects a desire to deny difference, assimilate the other and fortify a hegemonic position of the English culture.

Fifthly, the research shows that Pym's latest model of translation solutions (2016) is applicable to CBIs, with the exception of Compensation and Text Tailoring, which have not been detected in the compiled corpus (barring the novel's linguistic 'preface'). Finally, the implications of this study are that culture is not an unproblematic reality. In order to translate culture sensitively, the role and function of 
CBIs must not be underestimated because they determine the choice of the overall translation method. In this case study, the translator has considered the English readership and has tailored his translation solutions accordingly.

\section{Funding acknowledgement}

This paper is part of the KEGA 007PU-4/2015 Virtual interactive encyclopaedic English-Slovak and Slovak-English dictionary of general linguistics research grant project.

\section{Bibliographic references}

BAKER, M. 1992. In Other Words: a Course Book on Translation. London: Routledge. ISBN 0-415-03086-2.

BOHUCKA, B. 2016. Culture-specific Lexis in Translation (BA thesis). Presov: Presovska univerzita.

CRONIN, M. 2003. Translation and Globalization. New York: Routledge. ISBN 0415-27065-0.

CRONIN, M. 2006. Translation and Identity. London and New York: Routledge. ISBN 0-415-36465-5.

DURDUREANU, I. I. 2011. Translation of cultural terms: possible or impossible? In: Journal of Linguistic and Intercultural Education, n. 2, pp. 1-13. ISSN 2065-6599. Available at: 〈http://www.uab.ro/jolie/2011/4_durdureanu_irina.pdf>.

FLORIN, S. 1993. Realia in Translation. In: P. Zlateva (ed.).Translation as Social Action: Russian and Bulgarian Perspectives. London: Routledge, pp. 122-128. ISBN 978-0415076968.

GAMBIER, Y. 2007. Doubts and Directions in Translation Studies. Amsterdam and Philadelphia: John Benjamins. ISBN 978-9027216809.

GIBOVA, K. 2012. Translation Procedures in the Non-literary and Literary Text Compared. Norderstedt: BOD GmbH. ISBN 978-3-8448-0466-9.

HARVEY, M. 2000. A beginner's course in legal translation: the case of culturebound terms. In: Bern and Genéve: ASTTI/ETI, pp. 357-369.

HERMANS, T. 2007. Literary Translation. In: P. Kuhiwczak - K. Littau (eds.). A Companion to Translation Studies. Clevedon: Multilingual Matters, pp. 77-91. ISBN 978-1853599576.

HERVEY, S. - HIGGINS, I. 1992. Thinking Translation. London and New York: Routledge. ISBN 978-0415078160.

JAMES, K. 2002. Cultural implications for translation. In: Translation Journal, vol. 6, n. 4.4 ISSN 1536-7207. Available at: <http://translationjournal.net/journal/22delight.htm>.

KATAN, D. 2014. Translating Cultures. An Introduction for Translators, Interpreters and Mediators. London and New York: Routledge. ISBN 978-1900650731.

KLAUDY, K. 2003. Languages in Translation. Lectures on the theory, teaching and practice of translation. Budapest: Scholastica. ISBN 963-20689394.

LARSON, M. L. 1997. Meaning-Based Translation. A Guide to Cross-Language Equivalence. New York: University Press of America. ISBN 978-0761809487.

LEE, V. 2015. Thinking about the target reader: Using culture-specific lexis for intercultural communication. In: International Conference RCIC'15: Redefining Community in Intercultural Context, vol. 4, n. 2, pp. 383-387. Available at: 〈http://www.afahc.ro/ro/rcic/2015/rcic'15/AP/Lee\%202.pdf>.

LUNGU BADEA, G. 2004. Teoria culturemelor, teoria traducerii. TransTimisoara: Editura Universitatii de Vest. ISBN 973-8433-48-7. 
MAASOUM, S.M. H. - DAVTALAB, H. 2011. An Analysis of Culture-specific Items in the Persian Translation of "Dubliners" Based on Newmark's Model. In: Theory and Practice in Language Studies, vol. 1, n. 12, pp. 1767-1779. ISSN 17992591.

MIZANI, S. 2010. Cultural Translation. In: Translation Journal, vol. 13, n. 2. ISSN 1536-7207. Available at: <http://www.translationdirectory.com/articles/article1507.php>.

NEWMARK, P. 1988. A Textbook of Translation. London: Prentice Hall. ISBN 9780139125935.

PETRO, P. 2007. Rivers of Babylon. London: Garnett Press. ISBN 978-0953587841. PETRO, P. 2014. Specifika prekladu Rivers of Babylon P. Pistanka a Matkinovho Polnocneho denníka do anglictiny. In: Slovo a svet. Bratislava: Literarne informacne centrum. Available at: 〈http://www.litcentrum.sk/36170>.

PISTANEK, P. 2003. Rivers of Babylon. Bratislava: Slovart. ISBN 978-80-8085-6670 .

POPOVIC, A. 1975. Teoria umeleckeho prekladu. Bratislava: Tatran.

PYM, A. 2016. Translation Solutions for Many Languages. Histories of a flawed dream. London: Bloomsbury Academic. ISBN 978-1474261104.

RAKSANYIOVA, J. 2005. Preklad ako interkulturna komunikacia. Bratislava: AnaPress. ISBN 80-89137-09-1.

ROBINSON, D. 2012. Becoming a Translator. An Accelerated Course. $3^{\text {rd }}$ ed. London: Routledge. ISBN 978-0415615907.

SCHAFFNER, C. - WIESERMANN, U. 2001. Annotated Texts for Translation: English-German: Functionalist Approaches Illustrated. Cleveland: Cromwell Press. ISBN 978-1853594069.

SHIRYAEVA, V. - LUNGU BADEA, G. 2014. Subtitling: The Transfer of CultureSpecific Words in a Multidimensional Translation. In: Procedia: Social and Behavioral Sciences, vol. 149, pp. 883-888. ISSN 1877-0428. Available at: <http://www.sciencedirect.com/science/article/pii/S1877042814049830>.

SIPKO, J. 2011. Teoretické a sociálno-komunikacne vychodiska lingvokulturologie. Presov: Presovska univerzita. ISBN 978-80-555-0371-4.

TERESTYENYI, E. 2011. Translating Culture-specific Items in Tourism Brochures. In: SKASE Journal of Translation and Interpretation, vol. 5, n. 2, pp. 13-22. ISSN 1336-7811. Available at: 〈http://www.skase.sk/Volumes/JTI06/pdf_doc/02.pdf〉.

VENUTI, L. 1995. The Translator's Invisibility. New York: Routledge. ISBN 0-41511538-8.

WRIGHT, C. 2016. Literary Translation. London and New York: Routledge. ISBN 978-0-415-74532-1.

Words: 7493

Characters: 50237 (27,9 standard pages)

Assoc. Prof. Klaudia Bednarova-Gibova, PhD.

Institute of British and American Studies

University of Prešov

ul. 17 novembra 1, 08001 Prešov

Slovakia

klaudia.gibova@unipo.sk 